\title{
Development of Sustainable Community-Based Tourism in Kampong Grangsil, Jambangan Village, Dampit District, Malang Regency
}

\author{
Respati Wikantiyoso ${ }^{1}$, Diyah Sukanti Cahyaningsih ${ }^{2 *}$, Aditya Galih Sulaksono ${ }^{3}$, \\ Sri Widayati ${ }^{4}$, Dina Poerwoningsih ${ }^{1}$, Etikawati Triyosoputri ${ }^{1}$ \\ 1 Department of Architecture, University of Merdeka Malang \\ 2 Department of Accounting, University of Merdeka Malang \\ 3 Department of Information System, University of Merdeka Malang \\ 4 Department of Communication Science, University of Merdeka Malang \\ *Corresponding Author, Email: diyahsukanti@unmer.ac.id
}

Received: April 12, 2020 Accepted: Nov 11, 2020

Keywords: Sustainable Community, Community-Based Development, Sustainable Tourism Development.

\begin{abstract}
This discussion aims to find a sustainable community-based development model through a multi-stakeholder participatory approach. Rural planning in Indonesia has undergone significant changes in the last decade. Community-based development and participation is now an established agricultural development planning policy. Community participation produces planning and design decisions based on community needs, priorities, and affordability which often results in better and more realistic designs, plans, and programmes. In the development of kampung tourism, implementing community participation can reduce cost, increase the use of local resources, and socially empower the community. Kampong Grangsil is a hamlet of hardworking and civic-minded flower farmers. These farmers and members of their community organized and developed their village into a tourism destination that they named Kampoeng Boenga Grangsil (KBG) - Grangsil Flower Village. The high level of community participation as well as a Villages Partner Development Programme, made possible through the collaboration of village governments and university research teams, succeeded in making KBG into what it is today. Mentoring, through in-situ assistance (in Grangsil) and ex-situ assistance (at the Campus and Woodcraft Gallery), was carried out to strengthen resources. Throughout the mentoring programme, the research team acted as both a mediator and facilitator for developing Grangsil into an environmentally-friendly tourism destination. The role and involvement of mediators in the participatory development process increased the ability of communities to organize and build sustainable villages.
\end{abstract}

\section{INTRODUCTION}

The tourism industry is a rapidly growing industry that not only contributes to economic improvement but creates employment opportunities as well (Begum et al., 2014). The Indonesian government gave serious attention to equitable rural development through the Village Fund Policy under which almost all rural communities are encouraged to promote tourism by developing 
plans and designs according to the potential of each region. As centres of excellence, higher education facilities play a prominent role in ensuring that implementation of rural development is on the right track. Through the Indonesian Research and Community Services Board (LPPM), the University of Merdeka Malang (UNMER) launched the UNMER Village Development Programme as well as the Village Partner Development Programme which is in line with the UNMER Malang Working Programme (2016-2025).

In Indonesia, as well as most of Southeast Asia, the term 'kampong' can be best described as a village and is often used to refer to rural territories. At present, the goal is to develop villages that are modern, progressive, and urban while preserving their rustic country charm. Spatial sustainability is critical to conserving the unique local characteristics of the region through socio-cultural development and development of the region's various sectors while improving the quality of life of its community.

The development of rural tourism begins by determining the region's local characteristics from a socio-cultural and environmental standpoint (Kim \& Son, 2018; Tutuko \& Son, 2018). It investigates potential features such as the food, culture, and religious rituals as well as the natural environment. This can be classified as the creative aspect of rural tourism - making the tourism destination unique and interesting. Several factors influence the development of tourism villages, namely the uniqueness of the location, the involvement of major tourism actors (local communities), financing of tourism activities as well as the role of mobilizing community participation and engagement among stakeholders. Community-based tourism development increases the number of facilities, parks, cultural attractions, recreational visual experiences and benefits the quality of life of the community as well as gives them a sense of pride when their culture is accepted and respected by tourists (Lee \& Jan, 2019).

The creative aspect of the thematic village or kampong tourism development that is currently being executed by the community includes vase villages and Grangsil, where POKDARWIS (Tourism Awareness Group) developed a tourist destination in KBG. Grangsil is in Jambangan Village, Dampit District, Malang Regency, on the hilly and beautiful slopes of Mount Semeru (Figure 1). The fertile soil and adequate water sources available at Mount Semeru make it ideal to produce agricultural commodities, especially ornamental plants, and flowers. Grangsil's farming community has a relatively good work ethic, cooperation, and high morale.

Successful sustainable community development is an indicator of successful rural development. The key to a successful sustainable community requires the involvement of its community at every stage of the development process. In the context of community-based tourism development, community involvement is the primary focus. The main problem is how to maintain and increase community involvement in tourism village development. What role does sustainable community-based development play in the development of $\mathrm{KBG}$ as an effort to improve the resilience of rural communities?

The development of all stakeholders' interests is essential in the efforts to improve the livelihoods of related parties. Social ties, harmony, cooperation among community members as well as community social groups and organizations significantly contribute to increasing the role of social capital in rural development. 


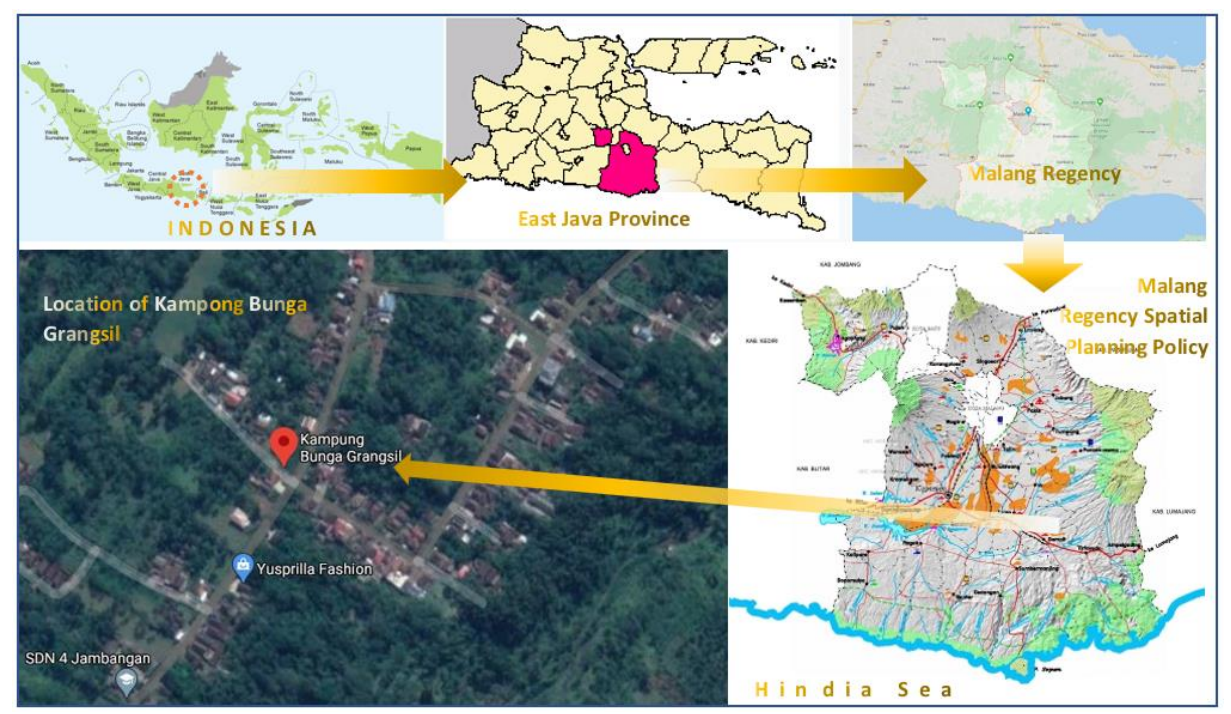

Figure 1. Location of Kampoeng Boenga Grangsil (KBG)

\section{SUSTAINABLE COMMUNITY-BASED RURAL VILLAGE TOURISM DEVELOPMENT}

Indonesia is one of the United Nations member states to adopt Sustainable Development Goals (SDGs), also known as the Global Goals, to achieve by 2030. Four out of 17 SDGs are closely linked to community-based rural tourism development (Wikantiyoso et al., 2019). The $11^{\text {th }}$ SDG aims to make cities and human settlements inclusive, safe, resilient, and sustainable. It calls upon its member states to maintain the soil and ecosystem, community empowerment, building resilient societies, strong institutions and partnerships to create a sustainable community and sustainable tourism development (Wikantiyoso et al., 2019). The challenge of sustainable tourism development is finding a model or approach that improves the social welfare of the community by using natural resources wisely to protect the environment while taking into consideration the available reserves of resources for future needs. This effort requires an approach that can synergize the interests of society (social and cultural), environment (natural and environmental resources), and the benefits of economic growth and change generation.

\subsection{Sustainable Community}

According to Community and Regional Resilience Institute (CARRI) (2013), community resilience is the ability of the community to minimize disruption to their daily lives and the local economy, and can quickly restore their capabilities, carry out business practices and restore the essential services needed for a complete and timely economic recovery. CARRI has developed the following definition for its use: Community resilience is the capability to anticipate risk, limit impact, and bounce back rapidly through survival, adaptability, evolution, and growth in the face of turbulent change.

The Desa Mitra (partner villages) Development Programme, a mentoring programme that was used while developing KBG, implements the following community-based development principles that are in keeping with the mandate of the 2015-2019 National Medium-Term Development Plan (RPJMN):

1) Community empowerment and development-oriented to the community's needs and local participation; 
2) Participatory rural development based on local wisdom plays an essential role in the process of sustainable community development;

3) To maintain the balance of agricultural ecosystems is directed at efforts to increase community empowerment, improve the quality of the local environment, conserve natural resources, preserve local cultural heritage, and create a balance of urban-rural development.

Human-centred development is needed to better align "development" with potential, community empowerment, and existing community resources (Figure 2). This strategy fosters an active role in increasing community participation (Sianipar et al., 2013; Prabhakaran, Nair, \& Ramachandran, 2014). It is possible to effectively increase community involvement through the following efforts:

1) Develop community participation via brainstorming forums on their involvement at the individual and community level.

2) Develop institutional structures and processes for community organizations that function following the principles of an independent community organization system.

3) Develop a territorial consumption-production system that is based on the principles of local ownership and control through the development of village-owned business entities. The purpose of increasing community participation is to improve the welfare and economy of the community through participation in building the economy of rural communities.
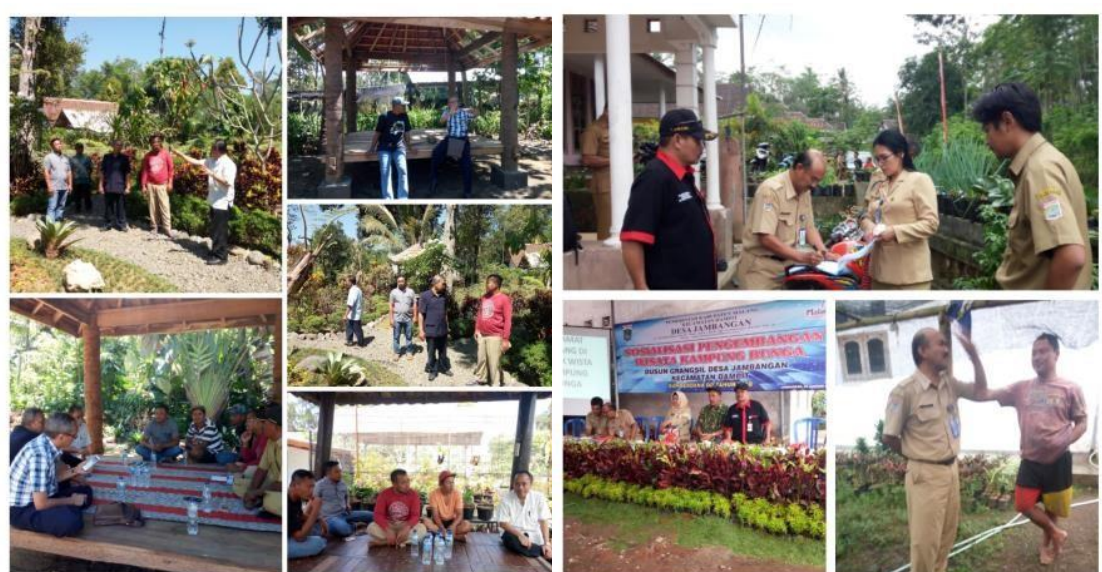

Figure 2. Socialising, brainstorming, and exploring the possibility of developing KBG into a tourism village

\subsection{Sustainable Tourism Development}

The sustainability of tourism development requires the synergy of ecological, community, and economic attributes. The World Tourism Organization (UNWTO; 1995) posits that sustainable tourism includes three dimensions: 1) ecological sustainability, 2) social and cultural viability, and 3) economic sustainability (Lee \& Jan, 2019). The success of developing tourist destinations is strongly influenced by the level of tourist visits to support the sustainability of tourism objects (Sangchumnong, 2019). In order to maintain the viability of a tourist destination, stakeholders must:

1) Evaluate market demand and changing trends (ecological-based tourism development, unique cultural values, and creative tourism development);

2) Increase the attractiveness of destinations to encourage loyalists to visit 
again, and

3) Improve management capacity (strengthen their institutions, organize themselves, plan and develop tourist destinations) to always be attractive for tourists to visit.

Sustainable tourism development needs to consider the sustainability of the business by observing market demand trends, marketing, and providing excellent service. In order to provide excellent tourism services, tourism managers must be able to manage, plan, and analyse the market (Sangchumnong, 2019). Managers must pay attention to tourist satisfaction so that the desire to visit again in the future arises. In this context, it is necessary for institutions to assist tourism managers.

\subsection{Community Empowerment in Tourism Development}

According to (Ratnasari \& Manaf, 2015), five factors influence the development of tourist villages. These factors are location uniqueness, the involvement of the local community (Prabhakaran, Nair, \& Ramachandran, 2014), financing, the role of figure drivers, and links between institutions. The development of domestic tourism requires several conditions, namely good accessibility, new objects, community actors, security, the existence of supporting facilities for tourism, the natural environment, and having links with other tourism objects and destinations (Pradinie et al., 2016). Linkages with other tourism objects, the role of stakeholders, and financing of tourism village activities are significant external factors (Falak, Chiun, \& Wee, 2014; Siri \& Chantraprayoon, 2017).

Most people in rural areas have fewer learning opportunities and visual experiences compared to those who live in cities. They have limited knowledge, skills and resources to be involved in tourism development and management (Razzaq et al., 2013). The essential expertise required is limited to people who have studied tourism through limited media. On the other hand, tourism managers need to possess development and tourism management capabilities.

Community empowerment (Razzaq et al., 2013) must be the goal of every community development project, eco-tourism development included. While development is defined as the flow of resources to society, empowerment encourages and attracts the full participation of all community members to change their entity from the inside out (Sianipar et al., 2013).

Learning depends largely on a person's knowledge and expertise in managing tourist destinations. Mentoring, as a part of community empowerment, requires experts in their fields. Centres of excellence, such as higher education institutions, that have experts on staff, are ideal for the mentoring process.

\section{RESEARCH METHODOLOGY}

This research uses the Participatory Action Research (PAR) method, which is implemented by mentoring and motivating stakeholders to participate in brainstorming ideas, empowering themselves, groups, organisations and the community, as well as developing tourism business planning policies that will be implemented independently in the future. 


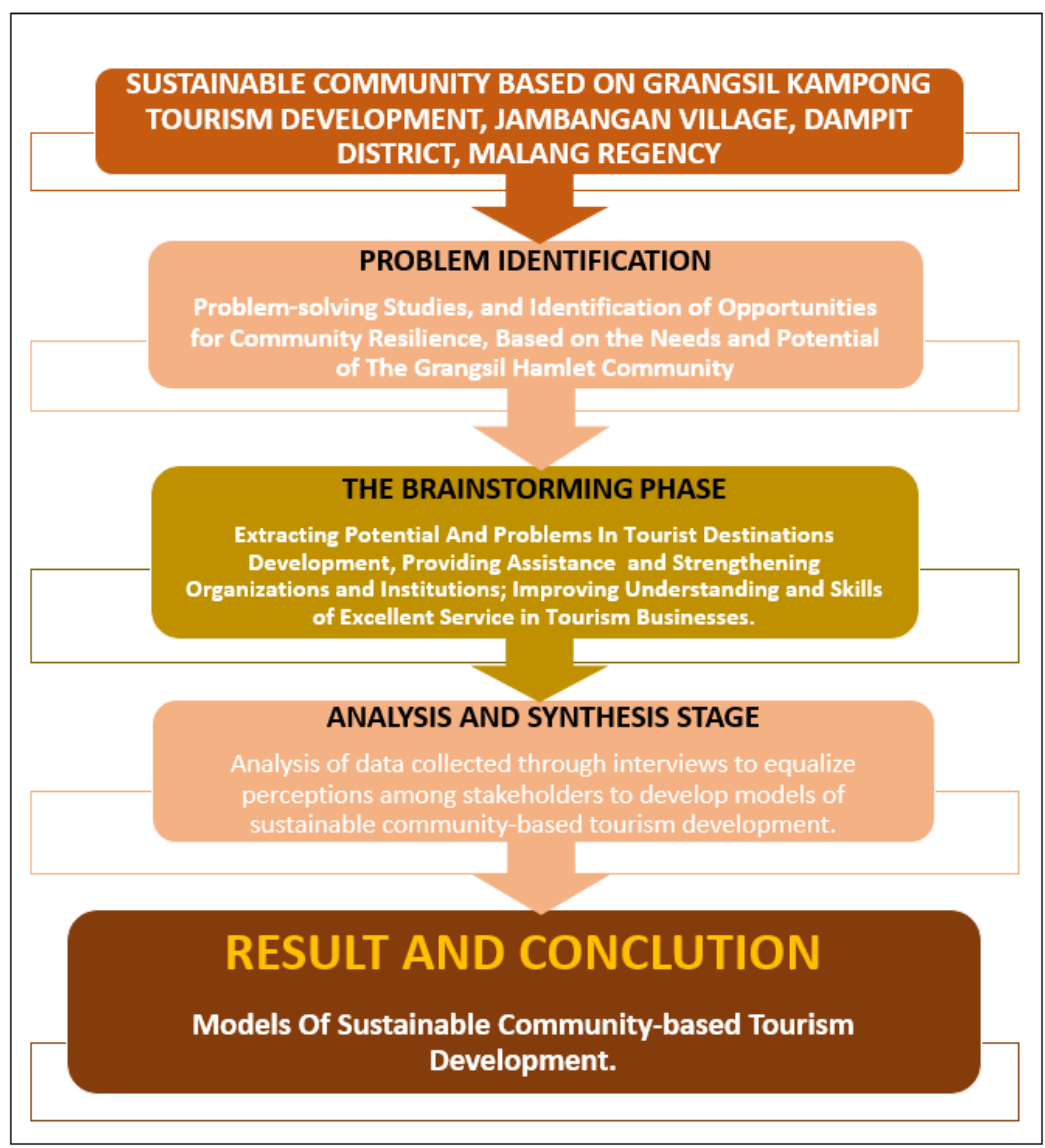

Figure 3. Research framework

This study aims to find a model of sustainable community-based development approaches through a process of assisted participatory tourism development. The three stages of this study (Figure 3) were:

1) Problem identification, problem-solving, and identification of opportunities for growth based on the needs and potential of the Grangsil community;

2) Brainstorming and identifying opportunities and obstacles in developing tourist destinations, aiding and strengthening organizations and institutions, and improving understanding and skills of service in ecological tourism businesses;

3) Analysing and synthesising data collected through interviews to equalize perceptions among stakeholders to develop models of sustainable community-based rural tourism development.

\section{RESULTS AND DISCUSSIONS}

Malang Regency is composed of 390 villages across 33 sub-districts. KBG is located on the south-western slope of Mount Semeru, in Jambangan Village, Dampit District. Dampit lies at the south end of Malang Regency, East Java. Its geographical position, topography, fertile soil, and cold climate make Jambangan Village an ideal location for ecological or agricultural tourism, while Grangsil's community of farmers are very supportive of tourism development.

Social Capital of Grangsil

Grangsil has extraordinary Social Capital, especially the high level of cooperation from its farming community. They are predominantly ornamental 
plant farmers with many years in the trade. Their area of expertise extends beyond ornamental horticulture to a diverse repertoire of agricultural commodities as well. For the past 20 years, the people of Grangsil have tailored their farm planning according to the agricultural needs of their economic partner, the island of Bali. Due to an increase of demand from the island province, the people of Grangsil transitioned from agriculture to decorative plant farming. Grangsil is rich with not only ornamental and flower farmers, but are skilled and knowledgeable park interpreters as well. This helps foster a sense of solidarity and togetherness in a common goal of bettering Grangsil's tourism industry. Partnerships and cooperation are vital social capital to realising sustainable development efforts (Yuliarmi, 2012; Cahyono \& Adhiatma, 2012; Sudirah, 2015). Based on the results of Sudirah's (2015) study, the values of community social capital motivate them to work more productively.

The social capital potential of the community is the basis for employing the use of the mentoring method. A city-based development model (Muslim, 2007) is the basis of the Assistance Model used to develop this Partner Village Development Programme.

Table 1. Community-oriented Organizations in Grangsil

\begin{tabular}{|c|c|c|c|c|}
\hline No. & $\begin{array}{l}\text { Grangsil Community } \\
\text { Organization Group }\end{array}$ & Field of Organization & $\begin{array}{c}\text { Number of } \\
\text { Administrator }\end{array}$ & $\begin{array}{l}\text { Number of } \\
\text { member }\end{array}$ \\
\hline 1 & $\begin{array}{l}\text { Pokdarwis (Tourism } \\
\text { Awareness Group) }\end{array}$ & $\begin{array}{c}\text { Tourism and } \\
\text { environmentalists }\end{array}$ & 15 & 30 \\
\hline 2 & Grangsil Flower Village Group & Tourism & 10 & 12 \\
\hline 2 & $\begin{array}{l}\text { Vegetable Farmers' Women } \\
\text { Group }\end{array}$ & Vegetable farmer & 12 & 38 \\
\hline 3 & Coffee Farmers Group & Coffee Farmer & 6 & 12 \\
\hline 4 & Youth organization & Youth & 10 & \\
\hline 5 & PKK (Dasa Wisma) group & Womenhood & 10 & 65 \\
\hline 6 & $\begin{array}{l}\text { Turonggo Arts and Cultural } \\
\text { Group }\end{array}$ & Art and Culture & 12 & 26 \\
\hline 7 & $\begin{array}{l}\text { Nur Hidayah Mosque Youth } \\
\text { Group }\end{array}$ & Religious & 16 & 40 \\
\hline 8 & $\begin{array}{l}\text { Small medium micro business } \\
\text { group }\end{array}$ & $\begin{array}{l}\text { Culinary and Economy } \\
\text { creative }\end{array}$ & 6 & 20 \\
\hline
\end{tabular}

A culture of cooperation is evident from the number of community organizations that have social and family concepts. The principles of Javanese life, which are compromise, harmony, and helping each other, become the essential capital in developing community resilience (Siri \& Chantraprayoon, 2017; Oosterlynck \& Bouchaute, 2013; Community and Regional Resilience Institute (CARRI), 2013). There are at least eight groups organized in various fields such as tourism, environmentalism, female farmers, social-cultural areas, religion, etc (see Table 1).

Social organizations that grow and develop are necessary social capital in emerging tourist destinations such as Grangsil. For example, the POKDARWIS (Tourism Awareness Group) functions as an ecological conservation organisation and is tasked with developing ecology-based tourism.

Turonggo's Arts and Cultural Group is a cultural group that develops and preserves the "Jaran Kepang" dance that adds to the cultural attractions. The Small-Medium Micro-Business Group creates creative culinary and other economic opportunities that address the needs of tourists and contributes greatly to the village's tourism. In its development, it requires all community groups to be united in the shared vision of developing ecology-based tourism (Grenier et al., 1993). Community empowerment is the key word for promoting tourism (Sutawa, 2012; Sianipar et al., 2013) in Grangsil. 


\subsection{Challenges of KBG Development}

In the development of KBG, the Assistance Model identified four main challenges to providing support for the development of KBG into a tourist destination, namely (1) Physical development of attractions, (2) Community empowerment, (3) Institutional development and, (4) Economic development. They are described as follows:

1) Challenges of physical development of attractions: Assistance is needed for efficient and artistic regional planning in (1) developing KBG's master plan, (2) design, and (3) regional governance. These were solved by planning facilities, implementing site design, and supporting facilities such as gazebos, tracks, kiosk settings, tourist routes, and directions. A discussion was held with the KBG team to solve the main problem of limited funds. The use of locally sourced materials was suggested and the design results are based on local wisdom (see Figure 4).

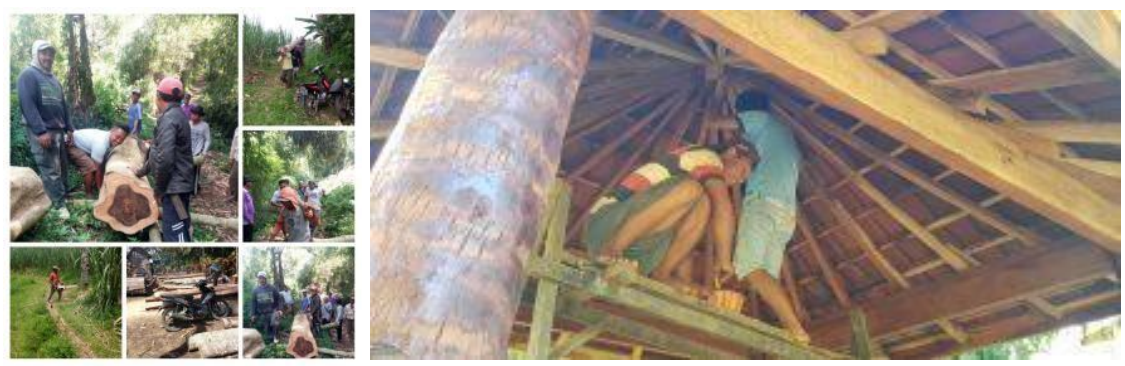

Figure 4. Use local wood materials used wisely and only when needed

2) Challenges of institutional development: (1) Strengthening KBG management organizations, (2) training local KBG tour guides, and (3) developing tourism management capabilities to address tourists' needs. Strengthening KBG management by assigning the abovementioned challenges to credible and reputable businesses most suited to provide adequate training to KBG managers.

3) Challenges with community empowerment: (1) Tourism management training including standard organization and job descriptions (Sutawa, 2012). Business entities are entitled to access funds in the form of corporate social responsibility (CSR). For example, if business entities can prove their association with state-owned companies or other parties. (2) CSR funds can significantly accelerate the development of a community (Gomez-Carrasco, Guillamon-Saorin, \& Garcia Osma, 2016), especially by providing the facilities that KBG requires.

4) Challenges of developing a creative economy: (1) Economic empowerment of a community through the development of distinctive alternative local products, be it souvenirs, culinary-related, or plants, by creating flower and souvenir kiosks; (2) increase productive activities for KBG tourists, including packaging of traditional wine snack products, improving the quality of local Grangsil coffee products, etc.

The successful implementation of the Village Partner Development Programme at Jambangan, with its iconic KBG and community-based tourism development model, serves as an example and increase competitiveness in other villages. 


\subsection{Community Empowerment through Community Participation}

As described above, community empowerment can increase community participation and is instrumental in the success of community-based tourism development. Through empowerment activities, communities are thought to assess how much (material and non-material) profit they stand to gain by participating in the mentoring programme. The average results of the brainstorming stage show varying degrees of participation. The highest participatory rate in the KBG Group is $85 \%, 70 \%$ for the Nur Hidayah Group, $60 \%$ in the Turonggo Group, and $45 \%$ in the Tourism Awareness Group (see Table 2).

The difference in the level of participation is strongly influenced by understanding the importance of the tourism village development programmes (Hidayati et al., 2016). The Tourism Awareness Group has the lowest rate $(45 \%)$ because most of its members are not natives of Grangsil and do not see the direct benefits of development.

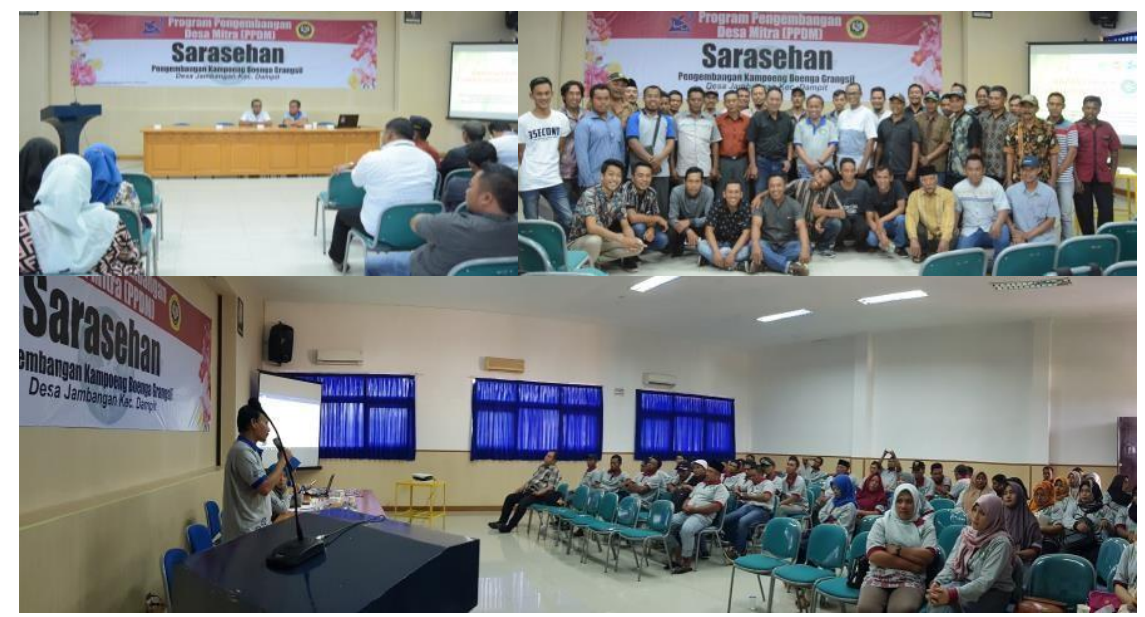

Figure 5. Brainstorming through ex-situ assistance

A relatively long time is required to be able to educate and change the understanding of the opportunities and benefits of developing tourism villages. The mentoring process, through in-situ and ex-situ assistance, has been running for only six months (Figure 5). In-situ mentoring was carried out in Grangsil, at the KBG site (see Figure 6). The in-situ mentoring method is the right choice considering the relative location of $\mathrm{KBG}(>38 \mathrm{~km}$ from Malang City).

Table 2. Rate of participation in empowerment activities

\begin{tabular}{|c|c|c|c|c|}
\hline No. & $\begin{array}{l}\text { Grangsil Community } \\
\text { Organization Group }\end{array}$ & Field of Organization & $\begin{array}{l}\text { Number of } \\
\text { member }\end{array}$ & $\begin{array}{l}\text { Participation } \\
\text { rate of } \\
\text { empowerment } \\
\text { activity }\end{array}$ \\
\hline 1 & $\begin{array}{l}\text { Pokdarwis (Tourism } \\
\text { Awareness Group) }\end{array}$ & $\begin{array}{l}\text { Tourism and } \\
\text { environmentalists }\end{array}$ & 30 & $45 \%$ \\
\hline 2 & Grangsil Flower Village Group & Tourism & 12 & $85 \%$ \\
\hline 3 & $\begin{array}{l}\text { Turonggo Arts and Cultural } \\
\text { Group }\end{array}$ & Art and Culture & 26 & $60 \%$ \\
\hline 4 & $\begin{array}{l}\text { Nur Hidayah Mosque Youth } \\
\text { Group }\end{array}$ & Religious & 40 & $70 \%$ \\
\hline
\end{tabular}

In-situ assistance is more flexible and comprises three types of activities: Planning and Designing, the process of absorbing aspirations; Implementation, the development process; and Supervision, joint evaluation. Meanwhile, ex-situ assistance provides more experience and understanding of the aspects of 
strengthening knowledge and skills, which is not possible at the service location (in-situ).

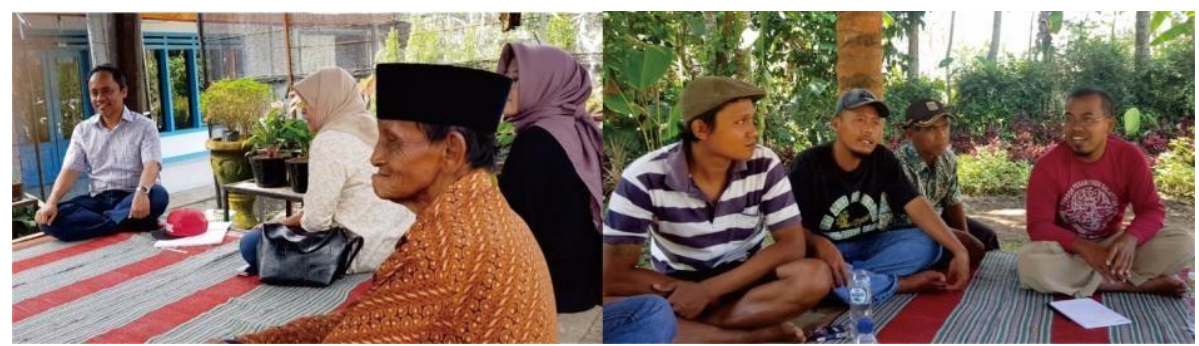

Figure 6. In-situ mentoring of POKDARWIS at KBG, Grangsil

Supporting social capital can motivate the Grangsil community to achieve its potential (Figure 7). They have so far successfully organized themselves to realize their KBGs. With POKDARWIS (Tourism Awareness Group), the Grangsil community set a target of achieving KBGs by integrating agricultural land with their collective home gardens. This collective awareness arises because of social solidarity (Table 3). Social capital raises collective awareness and thereby increases the participation of the Grangsil community. Community empowerment efforts are essential to the development process of sustainable tourism villages (Wikantiyoso et al., 2019). According to Durkheim (Oosterlynck \& Bouchaute, 2013), social solidarity creates a collective consciousness, which will be able to become a driver of development. From a mutual understanding of the need for progress, the camaraderie developed by building their facilities together in order to improve their standards of living became a very potent social capital.
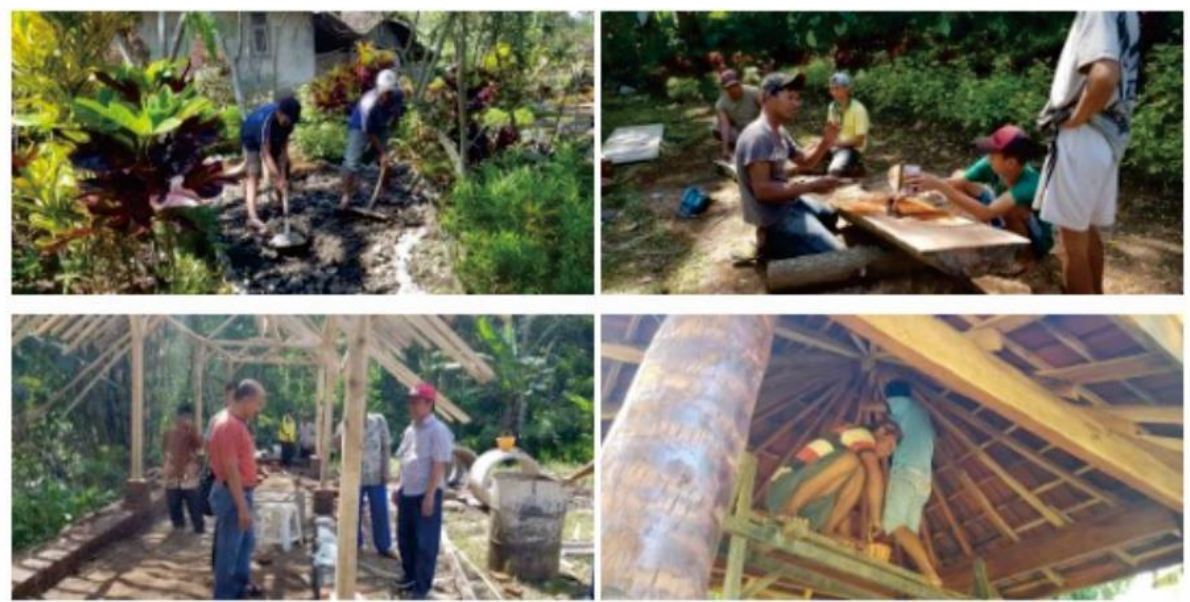

Figure 7. Cooperative activities to build facilities at KBG

Table 3. Role of Community participation in KBG tourism development

\begin{tabular}{|c|c|c|c|c|}
\hline No. & Stakeholders & Main Activity & $\begin{array}{c}\text { Role in development of assistance } \\
\text { activities/programmes }\end{array}$ & Leading Sector \\
\hline 1 & $\begin{array}{l}\text { Village Partner } \\
\text { Development } \\
\text { Programme }\end{array}$ & Brainstorming & $\begin{array}{l}\text { - Identification of challenges. } \\
\text { - Identification of community } \\
\text { aspirations. } \\
\text { - Identification of potential } \\
\text { social capital. } \\
\text { - Identification of possible } \\
\text { community groups. } \\
\text { - Identification of potential } \\
\text { development of tourist } \\
\text { destinations. }\end{array}$ & $\begin{array}{l}\text { The primary team of } \\
\text { Desa Mitra (Village } \\
\text { Partner } \\
\text { Development). }\end{array}$ \\
\hline
\end{tabular}




\begin{tabular}{|c|c|c|c|c|}
\hline No. & Stakeholders & Main Activity & $\begin{array}{l}\text { Role in development of assistance } \\
\text { activities/programmes }\end{array}$ & Leading Sector \\
\hline & & Empowerment & $\begin{array}{l}\text { - Facilitating efforts to increase } \\
\text { participation from women's } \\
\text { groups. } \\
\text { - Promoting efforts to empower } \\
\text { civil societygroups. } \\
\text { - Promoting efforts to increase } \\
\text { public participation. }\end{array}$ & $\begin{array}{l}\text { A trans-faculty team } \\
\text { supports the primary } \\
\text { Desa Mitra (Villages } \\
\text { Partner Development) } \\
\text { team. }\end{array}$ \\
\hline & & $\begin{array}{l}\text { Strengthening } \\
\text { of local } \\
\text { resources }\end{array}$ & $\begin{array}{l}\text { - Training and development of } \\
\text { KBG organizations. } \\
\text { - Increasing managerial } \\
\text { capabilities. } \\
\text { - Increasing ability of public } \\
\text { speaking. }\end{array}$ & $\begin{array}{l}\text { A trans-faculty team } \\
\text { supports the primary } \\
\text { Desa Mitra (Villages } \\
\text { Partner Development) } \\
\text { team. }\end{array}$ \\
\hline & & $\begin{array}{l}\text { Technical } \\
\text { assistance }\end{array}$ & $\begin{array}{l}\text { - Compilation of profiles. } \\
\text { - Preparation of a technical } \\
\text { plan. } \\
\text { - Creating functional plans } \\
\text { for KBG development. } \\
\text { - Construction of physical KBG } \\
\text { facilities. }\end{array}$ & $\begin{array}{l}\text { A trans-faculty team } \\
\text { supports the primary } \\
\text { Desa Mitra (Villages } \\
\text { Partner Development) } \\
\text { team. }\end{array}$ \\
\hline \multirow{4}{*}{2} & \multirow{4}{*}{$\begin{array}{l}\text { Civil Society } \\
\text { Organizations; } \\
\text { KBG } \\
\text { Management, } \\
\text { Tourism Awareness } \\
\text { Group, Female Farmers } \\
\text { Group, Youth } \\
\text { Organization, PKK } \\
\text { Group, Cultural Arts } \\
\text { Group, Mosque Youth } \\
\text { Group, etc. }\end{array}$} & Brainstorming & $\begin{array}{l}\text { - Actively express opinions. } \\
\text { - Actively submit proposals. } \\
\text { - Active discussion about } \\
\text { developing tourist } \\
\text { destinations. } \\
\text { - Providing a safeplace } \\
\text { for brainstorming. }\end{array}$ & $\begin{array}{l}\text { All members of civil } \\
\text { society organizations. }\end{array}$ \\
\hline & & Empowerment & $\begin{array}{l}\text { - Actively informing the } \\
\text { obstacles of HR development. } \\
\text { - Actively proposing a formof } \\
\text { capacity building. } \\
\text { - Providing a place for coaching } \\
\text { and training. }\end{array}$ & $\begin{array}{l}\text { KBG } \\
\text { Management, } \\
\text { Tourism Awareness } \\
\text { Group, Female } \\
\text { Farmers Group, Youth } \\
\text { Organization, PKK } \\
\text { Group, Cultural Arts } \\
\text { Group }\end{array}$ \\
\hline & & $\begin{array}{l}\text { Strengthening } \\
\text { of local } \\
\text { resources }\end{array}$ & $\begin{array}{l}\text { - Actively participating in } \\
\text { training and training } \\
\text { activities. } \\
\text { - Actively participating inex- } \\
\text { situ training. } \\
\text { - Becoming a volunteer. } \\
\text { - Active participation in } \\
\text { planning. }\end{array}$ & $\begin{array}{l}\text { KBGManagement, } \\
\text { Tourism Awareness } \\
\text { Group, Youth } \\
\text { Organization, Cultural } \\
\text { Arts Group. }\end{array}$ \\
\hline & & $\begin{array}{l}\text { Technical } \\
\text { assistance }\end{array}$ & $\begin{array}{l}\text { - Provide land forfacilities. } \\
\text { - Donate various plants. } \\
\text { - Active in public } \\
\text { trials/hearings. }\end{array}$ & KBG Management. \\
\hline \multirow{4}{*}{3} & \multirow{4}{*}{$\begin{array}{l}\text { External } \\
\text { Institution }\end{array}$} & & $\begin{array}{l}\text { The regional tourism } \\
\text { development } \\
\text { programme. }\end{array}$ & $\begin{array}{l}\text { Local government } \\
\text { support: village, } \\
\text { district and regency. }\end{array}$ \\
\hline & & $\begin{array}{l}\text { Development } \\
\text { of tourism } \\
\text { village } \\
\text { programmes }\end{array}$ & $\begin{array}{l}\text { - "One village, one } \\
\text { destination" programme. } \\
\text { - The creative economic } \\
\text { development } \\
\text { programme. }\end{array}$ & Government level. \\
\hline & & & $\begin{array}{l}\text { Village-Owned } \\
\text { Enterprise Development } \\
\text { Programme. }\end{array}$ & \\
\hline & & $\begin{array}{l}\text { Corporate social } \\
\text { responsibility }\end{array}$ & $\begin{array}{l}\text { - Alternative financingfor } \\
\text { KBG development. } \\
\text { - Assistance to Small and } \\
\text { Micro Enterprises } \\
\text { (SMEs). }\end{array}$ & $\begin{array}{l}\text { National private } \\
\text { company. }\end{array}$ \\
\hline
\end{tabular}




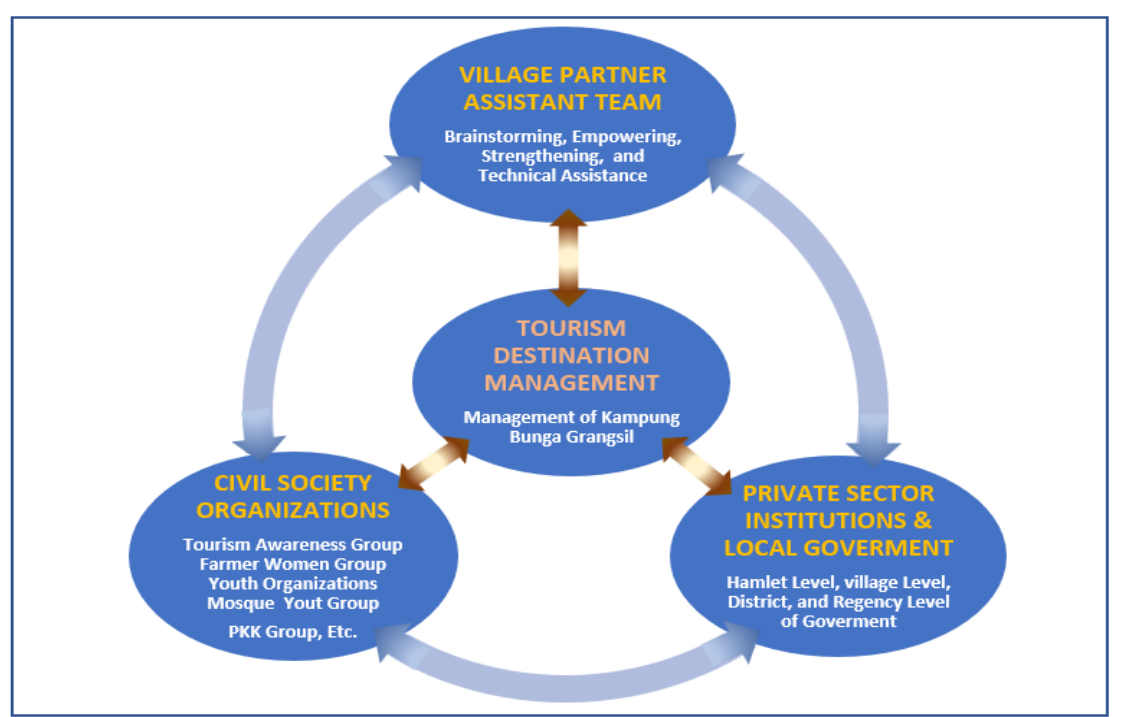

Figure 8. Models of sustainable community-based tourism development

\section{CONCLUSIONS}

The Desa Mitra (Village Partner Development) team served as both a mediator and facilitator in developing Kampoeng Boenga Grangsil (KBG) into a tourist destination and guiding the community towards independence. The role and involvement of mediators in the participatory development process increased the ability of the community to organize themselves to build their village. It was a learning process that evaluated the village's ability and resilience in realizing its aspirations of becoming a tourism village.

The development of KBG into a Sustainable community-based ecotourism destination required the involvement of three main parties, namely: (1) Village Partner Development team; (2) Civil society organizations in Grangsil, and (3) External institutions, local government and private institutions. The potential and interests of the three parties synergistically contributed to developing Kampoeng Boenga Grangsil (KBG) (Figure 8).

\section{ACKNOWLEDGEMENT}

I want to express my gratitude to the people of Grangsil, Jambangan Village, Dampit District, Malang Regency for their time and participation in this research. This study was funded by the Directorate of Research and Community Service, Directorate General of Strengthening Research and Community Services, Ministry of Research, Technology and Higher Education via Community Service Contract Number: 111 / SP2H / PPM / DRPM / 2019. The Desa Mitra (Village Partner Development) Programme is a Community Service activity that researchers also use as a multi-year research activity. The findings and conclusions are beneficial for the development of KBG as a sustainable ecological tourist destination. Thank you again to all stakeholders who have provided their time and support to researchers. 


\section{REFERENCES}

Begum, H., Er, A. C., Alam, A. S. A. F., \& Sahazali, N. (2014). "Tourist's Perceptions Towards the Role of Stakeholders in Sustainable Tourism". Procedia - Social and Behavioral Sciences, 144, 313-321. doi: https://doi.org/10.1016/j.sbspro.2014.07.301.

Cahyono, B., \& Adhiatma, A. (2012). "Peran Modal Sosial Dalam Peningkatan Kesejahteraan Masyarakat Petani Tembakau Di Kabupaten Wonosobo". Proceedings of Conference In Business, Accounting, And Management (CBAM), pp. 131-144.

Community and Regional Resilience Institute (CARRI). (2013). "Definitions of Community Resilience: An Analysis". Retrieved from https://s31207.pcdn.co/wpcontent/uploads/2019/08/Definitions-of-community-resilience.pdf.

Falak, S., Chiun, L. M., \& Wee, A. Y. (2014). "A Repositioning Strategy for Rural Tourism in Malaysia - Community's Perspective". Procedia - Social and Behavioral Sciences, 144, 412415. doi: https://doi.org/10.1016/i.sbspro.2014.07.310.

Gomez-Carrasco, P., Guillamon-Saorin, E., \& Garcia Osma, B. (2016). "The Illusion of Csr: Drawing the Line between Core and Supplementary Csr". Sustainability Accounting, Management and Policy Journal, 7(1), 125-151. doi: https://doi.org/10.1108/SAMPJ-122014-0083.

Grenier, D., Kaae, B. C., Miller, M. L., \& Mobley, R. W. (1993). "Ecotourism, Landscape Architecture and Urban Planning". Landscape and urban planning, 25(1), 1-16. doi: https://doi.org/10.1016/0169-2046(93)90119-X.

Hidayati, R., Sudaryono, Wijono, D., \& Prayitno, B. (2016). "Tourism Development of Historical Riverbanks in Jatinom Village". Procedia - Social and Behavioral Sciences, 227, 650-655. doi: https://doi.org/10.1016/j.sbspro.2016.06.128.

Kim, Y., \& Son, Y.-H. (2018). "The Role of Tourist Behaviour in the Determination of Tourist Attractions

Emerging Tourist Destinations in Jeju Island, South Korea through Self-Wedding Photography". International Review for Spatial Planning and Sustainable Development, 6(4), 62-75. doi: https://doi.org/10.14246/irspsd.6.4_62.

Lee, T. H., \& Jan, F.-H. (2019). "Can Community-Based Tourism Contribute to Sustainable Development? Evidence from Residents' Perceptions of the Sustainability". Tourism Management, 70, 368-380. doi: https://doi.org/10.1016/j.tourman.2018.09.003.

Muslim, A. (2007). "Pendekatan Partisipatif Dalam Pemberdayaan Masyarakat". Jurnal Aplikasi Ilmu-Ilmu Agama, 8(2), 89-103.

Oosterlynck, S., \& Bouchaute, B. (2013). "Social Solidarities: The Search for Solidarity in Sociology". OASeS Research Centre.

Prabhakaran, S., Nair, V., \& Ramachandran, S. (2014). "Community Participation in Rural Tourism: Towards a Conceptual Framework". Procedia - Social and Behavioral Sciences, 144, 290-295. doi: https://doi.org/10.1016/j.sbspro.2014.07.298.

Pradinie, K., Pamungkas, A., Idajati, H., Krisdianto, J., \& Ardianta, D. A. (2016). "Tourism Innovation System (Sida) in Pringgabaya Based on Sea Waves Energy Development Initiative". Procedia - Social and Behavioral Sciences, 227, 680-685. doi: https://doi.org/10.1016/j.sbspro.2016.06.132.

Ratnasari, D. J., \& Manaf, A. (2015). "Tingkat Keberhasilan Program Penataan Lingkungan Permukiman Berbasis Komunitas (Studi Kasus: Kabupaten Kendal Dan Kota Pekalongan)". Jurnal Pengembangan Kota, 3(1), 40-48.

Razzaq, A. R. A., Mohamad, N. H., A.Kader, S. S. S., Mustafad, M. Z., Hadi, M. Y. A., Hamzah, A., \& Khalifah, Z. (2013). "Developing Human Capital for Rural Community Tourism: Using Experiential Learning Approach". Procedia - Social and Behavioral Sciences, 93, 1835-1839. doi: https://doi.org/10.1016/j.sbspro.2013.10.126.

Sangchumnong, A. (2019). "Development of a Sustainable Tourist Destination Based on the Creative Economy: A Case Study of Klong Kone Mangrove Community, Thailand". Kasetsart Journal of Social Sciences, 40(3), 642-649. doi: https://doi.org/10.1016/j.kjss.2018.02.002.

Sianipar, C. P. M., Yudoko, G., Adhiutama, A., \& Dowaki, K. (2013). "Community Empowerment through Appropriate Technology: Sustaining the Sustainable Development". Procedia Environmental Sciences, 17, 1007-1016. doi: https://doi.org/10.1016/j.proenv.2013.02.120.

Siri, R., \& Chantraprayoon, O. S. (2017). "Local Community Participatory Learning with a Nature Interpretation System: A Case Study in Ban Pong, Sansai District, Chiang Mai, Thailand". Kasetsart Journal of Social Sciences, 38(2), 181-185. doi: https://doi.org/10.1016/j.kjss.2016.04.003.

Sudirah. (2015). "Modal Sosial Dan Pemberdayaan Masyarakat Desa Wisata". Proceedings of 
Prosiding Seminar Nasional Fakultas Ilmu Sosial dan Ilmu Politik, Universitas Terbuka UTCC, pp. 148-156.

Sutawa, G. K. (2012). "Issues on Bali Tourism Development and Community Empowerment to Support Sustainable Tourism Development". Procedia Economics and Finance, 4, 413422. doi: https://doi.org/10.1016/S2212-5671(12)00356-5.

Tutuko, P., \& Son, Y.-H. (2018). "Editorial Introduction

Urban-Rural Regeneration and Cultural Sustainability". International review for spatial planning and sustainable development, 6(4), 1-4. doi: https://doi.org/10.14246/irspsd.6.4_1.

Wikantiyoso, R., Sukanti Cahyaningsih, D., Sulaksono, A., \& Widayati, S. (2019).

"Empowerment and Strengthening of Community Resilience in Developing Ecotourism Destination in Grangsil Hamlet, Malang Regency, Indonesia". Proceedings of 3rd Endinamosis 2019 International Conference on "Empowering rural areas in the Industry 4.0 era", Bandung, Indonesia.

Yuliarmi, N. N. (2012). "Peran Modal Sosial Dalam Pemberdayaan Industri Kerajinan Di Provinsi Bali". PIRAMIDA, 7(2). 